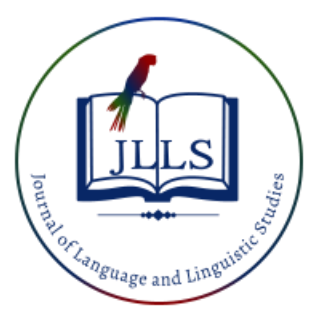

Available online at www.jlls.org

JOURNAL OF LANGUAGE

AND LINGUISTIC STUDIES

ISSN: 1305-578X

Journal of Language and Linguistic Studies, 16(3), 1189-1202; 2020

\title{
Considerations on the new curriculum of English Language Teaching programmes
}

\author{
F. Özlem Saka a 1 iD \\ ${ }^{a}$ Akdeniz University, Antalya, Turkey \\ APA Citation:
}

\begin{abstract}
Saka, F. Ö. (2020), Considerations on the new curriculum of English language teaching programmes. Journal of Language and Linguistic
Studies, 16(3), 1189-1202.

Submission Date:28/02/2020

Acceptance Date:30/06/2020
\end{abstract}

\begin{abstract}
The curricula of all departments in the faculty of education have been designed by Higher Education Council unlike the curricula of other faculties in Turkish higher education. After the regulation in 2006, all faculties of education throughout Turkey carried out the curricula until the new changes in 2018. It is the same for English Language Teaching departments. In 2018 Higher Education Council changed the curricula and new programmes were sent to be applied in the 2018-2019 academic year. The most striking change is that there are optional course pools under the titles of special field education, pedagogical knowledge and general knowledge. Compared to the programme in 2006, total class hours are decreased but the numbers of courses are increased. School Practice course based on mostly observation in real atmosphere is replaced with a new 6 - hour practicum course called Teaching Practice I. It is certain that the efficiency of the programme will be shown when it has been carried out completely. However, it is possible to evaluate the new programme, by examining and comparing it with the former one. This study compares the new programme and the former one in terms of the numbers, class hours, the ratio in the programme, ECTS credits and contents of the courses that belong to the field education, pedagogical knowledge and general knowledge. As a result, it has been proposed that the new programme will not meet the needs of qualified teacher training especially in terms of special field knowledge and field education.
\end{abstract}

(C) 2020 JLLS and the Authors - Published by JLLS.

Keywords: foreign language teaching; curriculum design; teacher training; foreign language teacher

\section{Introduction}

Language teacher training, one of the main parts of language teaching and learning process, has been the concern of all times. To improve the quality of instruction in language classrooms, it is necessary to develop teacher training process as well. This process involves knowing basic concepts and principles and applying them to teaching with the ability to present those principles and practices in class (Richards \& Farrell, 2005). Competent teachers have principles, knowledge and skills which are fundamentally integrated in their teaching (Pettis, 2002). They also have to know about the language, which is the

\footnotetext{
${ }^{1}$ Corresponding author. Tel.: +90-242-310-6623

E-mail address: ozlemsaka@akdeniz.edu.tr
} 
subject they are teaching (Harmer, 2007). For a language teacher, language proficiency is of great importance because it affects the teacher's teaching skills as well (Richards, 2000). For example, a teacher with inadequate proficiency in the target language cannot use questions effectively or give comprehensible explanations in class (Richards, 2000). Besides, English language teaching is a profession in which knowledge and practice should be integrated (Randoll \& Thornton, 2001; Kumaravadivelu, 1999). Therefore, the syllabus for language teacher training should include both theory and practice. Kaş (1989) states that in order to improve the quality of the teacher, foreign language teaching programmes should contain optional courses as well as compulsory theoretical courses in foreign language teaching programmes. He also suggests that a second foreign language should be taught, the programme should include Turkish education and courses for teaching practice. Alptekin (1994) believes that students are not good enough at foreign language skills and all the courses should be given in the target language to make students more qualified before graduation. According to Orhan (2017), language courses are effective on condition that teachers are qualified. Therefore, to improve language teaching process, teachers are supported in both pre-service and in-service periods in order to catch up with and apply the current trends.

Under the effect of the CEFR (Common European Framework of Reference for Languages) and constructivism, MoNE (Ministry of National Education) planned to review language programmes applied in different levels. New regulations have been made in different dimensions for a long time to improve the quality of education in foreign language teaching, which is a problematic issue in our country. With this aim, syllabuses were designed for the courses at the primary, secondary and high school levels according to the levels of the CEFR, then, books were written for the new syllabuses and teachers were informed about the novelties and changes in the ELT (English Language Teaching) field.

Teacher training period is the most important matter which determines teacher quality. The programmes of faculty of education, established in the universities since 1982, are designed by HEC (Higher Education Council) and expected to be adopted in all departments of faculty of education. By this way, it is provided that all faculties carry out the same programme in the teacher training process. HEC had some regulations in the programmes of faculty of education in 1997 and 2006 and these programmes were applied throughout the country until 2018.

\subsection{Literature review}

There are studies about 2006 programme in the literature. In the study of Seferoğlu (2006), ELT students criticize the current programme as it does not include enough opportunities for practice. Focusing on the importance of practice in micro- teaching and teaching practice applications, they want more courses based on practice. Furthermore, it would be better for them to have school experience and practice teaching from many different teachers, with students at different levels and in different school settings.

Coşkun and Daloğlu (2010) have reached these results in their study on the current programme: Students criticize the programme for that it includes limited amount of practice. They find teacher training courses are mostly based on theory. According to the lecturers, although the programme supports professional development, skill courses in the first year are insufficient to improve students' linguistic competence. Both students and lecturers suggest that courses including practice should be increased. Lecturers are also in favour of the necessity of the courses such as School Experience, Material development, Teaching Language Skills and Literature and Language Teaching.

In his study, Karakaş (2012) discusses the strengths and weaknesses of the programme applied in ELT Departments since 2006. He is in favour of having new courses such as Listening and Pronunciation, Second Foreign Language and Community Service, of separation of the courses for speaking and listening skills such as Listening and Pronunciation and Oral Communication Skills, and 
of Literature and Language Teaching for its new pedagogical content. He approves of the necessity of Computer I and II as they help students use technology, and Second Foreign Language because it is necessary for a modern language teacher to know another foreign language. However, he finds the lack of courses on using technology in ELT and target culture as weaknesses and he calls the programme out of date. Besides, he believes that changing the place of School Experience course is a wrong decision. $\mathrm{He}$ also criticizes the programme because it is not based on a teaching philosophy, it does not include enough practice, it includes only a few optional courses and because there is only one classroom management course.

Yavuz and Topkaya (2013) explore the perceptions of the ELT students on the curriculum regulations in 2006. Students mention their satisfaction with the new courses such as Drama and Public Speaking, having a course for Foreign Language Teaching Approaches and Methods for two terms, the content of Contextual Grammar I and II and Materials Development in Foreign Language Teaching. They do not like the place of the courses such as Language Acquisition, Linguistics, Approaches and Methods in Foreign Language Teaching and Scientific Research Methods in the programme; the structure of Community Service course; the content of Teaching Language Skills course; the credits of Scientific Research Methods and Listening and Pronunciation; integration of reading and writing courses; the removal of School Experience I and Advanced Writing courses. Nevertheless, their views on the programme are generally positive.

Uzun (2016) wants his students to evaluate 2006 programme. Students give the highest points to the courses such as Approaches and Methods in Foreign Language Teaching, Teaching English to Young Learners, Testing and Evaluation in Language Teaching, Materials Development in Language Teaching, School Experience and Teaching Practice for being the most effective courses. They say Materials Development course develops their creativity, but it causes a waste of a lot of time and money. They inform that they benefit a lot from Testing and Evaluation in Language Teaching and Oral Communication Skills; and that Public Speaking gives them opportunity to use the language. They also think that Second Foreign Language course is necessary. They criticize Atatürk's Principles and Revolution History course for being based on memorising; Computer courses for being too difficult in terms of content and practice. They want literature to be taught in relation to using it in language classrooms rather than analysing literary texts. When they evaluate the programme in general, they find it unsuccessful.

After a lot of changes in the foreign language teaching programmes at primary, secondary and high school levels, there is still a foreign language learning problem, HEC and MoNE have had some studies to find and solve the problems. Determining some objectives related to the teachers, MoNE has put them into practice (MEB, 2017). In the study called Teacher Strategy Paper, there are a lot of objectives such as the improvement of teacher training period, teachers' personal and professional development and better working conditions for teachers. In the paper it is asserted that in order to increase the success of teacher training programmes, they should include more teaching practice (MEB, 2017). With this information, HEC has decided to make changes in the programmes of faculty of education (YÖK, 2018). According to HEC, teachers should be qualified, highly motivated and sophisticated with special field knowledge, general knowledge and pedagogical knowledge, and behave according to the values and ideals of the community (YÖK, 2018). Collecting special field knowledge, pedagogical knowledge, pedagogical field knowledge in three groups, HEC explains them as in the following: Special field knowledge is the knowledge of the main concepts in the special field. Pedagogical knowledge is the general knowledge about teaching and learning. Pedagogical field knowledge is the knowledge of how to teach that special field (YÖK, 2018). Examining teacher training period, HEC aims at a curriculum which combines theory and practice, has standard ECTS credits all over the country and which is compatible with the Bologna process (YÖK, 2018). The programme designed for all teaching fields came into effect in 2018 (YÖK, 2018). 
Comparing the 2006 programme and 2018 programme, Yaman (2018) mentions that the course called Approaches for English Learning and Teaching is planned two hours, which is not enough to teach this course with practice. Yaman (2018) is in favour of a large number of optional courses. He criticizes the new programme as it includes only theoretical courses and he puts the emphasis on the fact that the teacher candidates will be qualified in terms of general pedagogical knowledge with this programme, but special field education is left behind.

It is certain that the efficiency of a teaching programme can be understood when it is applied, in other words, with the knowledge, skills and qualifications that teacher candidates reflect after their graduation. However, the new programme can be discussed by comparing it with the former one. With this idea, courses for special field education (from now on it is called English language teaching), general knowledge and pedagogical knowledge in 2006 and 2018 programmes are compared in terms of some variables. In this article, 2006 programme is called 'former' programme, 2018 programme as 'new' programme.

\subsection{Research questions}

What kind of differences are there between the former and new programmes related to the courses for English language teaching, general knowledge and pedagogical knowledge in terms of

1. their numbers?

2. their hours?

3. their ratios in the programme?

4. their ECTS (European Credit Transfer System) credits?

5. their contents?

\section{Method}

In the study designed in the qualitative method, document analysis is used. Documents are qualified data about facts and analysing such data can increase the reliability and validity of the qualitative research (Yıldırım \& Şimşek, 2013). In this study, ELT curriculum in the 2006 document (YÖK, 2007) and the 2018 document (YÖK, 2018) are compared and evaluated in terms of education of qualified teacher candidates.

\section{Results}

\subsection{Results for the $1^{\text {st }}$ research question}

The differences between the former and new curriculum in terms of the numbers of the lessons related to English language teaching, general knowledge and to pedagogical knowledge are as in Table 1:

Table 1. Distribution of numbers of the lessons

\begin{tabular}{lcc}
\hline Fields in the programme & Former Programme & New Programme \\
\hline ELT & 34 & 32 \\
General knowledge & 11 & 12 \\
Pedagogical knowledge & 13 & 22 \\
Total & 58 & 66 \\
\hline
\end{tabular}


Courses in both programmes are collected in three main groups such as English language teaching, general education and pedagogical knowledge. There are 34 courses for English language teaching in the former programme, in the new one this number decreases to 32 . While the number of the courses related to general knowledge was 11 in the former programme, in the new one 12 courses for general knowledge can be seen. The number of the pedagogical courses was 13 but in the new one this number increases to 22 . The total number of all the courses in the former programme was 58 , it is 66 in the new one.

\subsection{Results for the $2^{\text {nd }}$ research question}

When both programmes are examined in terms of class hours, it is seen that there were 175 class hours in the former programme but this number decreases to 155 in the new one. When Table 2 is examined, it is recognised that while the class hours for English language teaching decrease from 101 to 71 , the class hours for pedagogical knowledge increase from 44 to 56 . In the new programme, the class hours for English language teaching itself (71) is less than the total class hours of courses belong to other two fields $(28+56=84)$.

Table 2. Class Hours Distribution

\begin{tabular}{lcc}
\hline Fields in the programme & Former Programme & New Programme \\
\hline ELT & 101 & 71 \\
General knowledge & 30 & 28 \\
Pedagogical knowledge & 44 & 56 \\
Total & 175 & 155 \\
\hline
\end{tabular}

Table 3 shows the distribution of class hours according to terms:

Table 3. Class hours for terms

\begin{tabular}{|c|c|c|c|c|c|}
\hline $1^{\text {st }}$ Term & Former P. & New $P$. & $2^{\text {nd }}$ Term & Former P. & New $P$. \\
\hline ELT & 12 & 8 & ELT & 15 & 10 \\
\hline General K. & 9 & 10 & General K. & 6 & 7 \\
\hline Pedagogical K. & 3 & 4 & Pedagogical K. & 3 & 4 \\
\hline Total & 24 & 22 & Total & 24 & 21 \\
\hline $3^{\text {rd }}$ Term & & & $4^{\text {th }}$ Term & & \\
\hline ELT & 15 & 10 & ELT & 12 & 10 \\
\hline General K. & 2 & 2 & General K. & 2 & 2 \\
\hline Pedagogical K. & 5 & 8 & Pedagogical K. & 8 & 6 \\
\hline Total & 20 & 18 & Total & 22 & 18 \\
\hline $5^{\text {th }}$ Term & & & $6^{\text {th }}$ Term & & \\
\hline ELT & 17 & 10 & ELT & 16 & 10 \\
\hline General K. & 4 & 2 & General K. & 3 & 2 \\
\hline Pedagogical K. & 2 & 6 & Pedagogical K. & 3 & 6 \\
\hline Total & 23 & 18 & Total & 22 & 18 \\
\hline $7^{\text {th }}$ Term & & & $8^{\text {th }}$ Term & & \\
\hline ELT & 7 & 8 & ELT & 7 & 5 \\
\hline General K. & 2 & 3 & General K. & 2 & 0 \\
\hline Pedagogical K. & 10 & 12 & Pedagogical K. & 12 & 12 \\
\hline Total & 19 & 23 & Total & 21 & 17 \\
\hline
\end{tabular}


There is a fall in the class hours for English language teaching according to the terms but the class hours for pedagogical knowledge courses increase. English language teaching is a field which has its own teaching approaches, methods and techniques. It is important to gain skills mainly in English language teaching to improve the English language teacher quality.

In order to evaluate class hours, it is necessary to have a look at the theoretical and practice courses in the programme. The number of the theoretical courses was dropped off from 143 to 141. Practice hours were decreased from 32 to 14 . There is a devastating fall in the class hours of theoretical courses related English language teaching. There are no courses for practice at all. It is surprising to have so few courses for practice in a field such as English language teaching.

Table 4. Distribution of theoretical and practice courses

\begin{tabular}{|c|c|c|c|c|}
\hline & \multicolumn{2}{|c|}{ Former Programme } & \multicolumn{2}{|c|}{ New Programme } \\
\hline $\begin{array}{l}\text { Fields in the } \\
\text { programme }\end{array}$ & $\begin{array}{l}\text { Theoretical } \\
\text { courses }\end{array}$ & $\begin{array}{l}\text { Practice } \\
\text { courses }\end{array}$ & $\begin{array}{l}\text { Theoretical } \\
\text { courses }\end{array}$ & Practice courses \\
\hline ELT & 91 & 10 & 71 & 0 \\
\hline $\begin{array}{l}\text { General } \\
\text { knowledge }\end{array}$ & 22 & 8 & 26 & 2 \\
\hline $\begin{array}{l}\text { Pedagogical } \\
\text { Knowledge }\end{array}$ & 30 & 14 & 44 & 12 \\
\hline Total & 143 & 32 & 141 & 14 \\
\hline
\end{tabular}

\subsection{Results for the $3^{\text {rd }}$ research question}

When the former and new programmes are compared in terms of the ratio of the courses related to English language teaching, general knowledge and pedagogical knowledge, it is seen that the ratio for English language teaching is lower than 50\%. The total ratio for general knowledge and pedagogical knowledge is higher than the ratio for English language teaching.

Table 5. Ratio of the courses according to the fields

\begin{tabular}{lcc}
\hline Fields in the programme & Former Programme & New Programme \\
\hline ELT & $58 \%$ & $46 \%$ \\
General knowledge & $17 \%$ & $18 \%$ \\
Pedagogical knowledge & $25 \%$ & $36 \%$ \\
Total & $100 \%$ & $100 \%$ \\
\hline
\end{tabular}

\subsection{Results for the $4^{\text {th }}$ research question}

When the new and former programmes are evaluated in terms of ECTS credits for English language teaching, general knowledge and pedagogical knowledge, it can be crucial for HEC to determine ETCS credits in order to have standardization in all faculties of education. In the former programme, ECTS credits, which were introduced with the Bologna process, were determined after the calculation of students' work load and time they spend for each course (https://uluslararasi.yok.gov.tr/Documents/yay\%C4\%B1nlar/yuksekogretimde_yeniden_yapilanma_66 _soruda_bologna_2010.pdf ) and these credits could change from department to department, from faculty to faculty. When ECTS credits are discussed, the new and the former programmes are not compared, and the situation is explained only by examining the new programme because ECTS credits were different in all ELT departments throughout Turkey. The distribution of ECTS credits in the new programme for English language teaching, general knowledge and pedagogical knowledge is thought- 
provoking. The total ECTS credits for English language teaching are 107, for general knowledge is 42 and for pedagogical knowledge is 91 . As can be seen from the table below, total ECTS credits for general knowledge and pedagogical knowledge is more than the credits for English language teaching.

Table 6. ECTS credits of the new programme

\begin{tabular}{lc}
\hline Fields in the Programme & New Programme \\
\hline ELT & 107 \\
General knowledge & 42 \\
Pedagogical knowledge & 91 \\
Total & 240 \\
\hline
\end{tabular}

The distribution of ECTS credits reveals the seriousness of the situation. ECTS credits for English language teaching courses in the first two terms and in the last two terms are lower than the total ECTS credits for the courses related to general knowledge and pedagogical knowledge in the same terms. This will cause students to think that the courses with lower ECTS credits are less important. Besides, when students get higher grades for the courses with high ECTS credits, they will be regarded as successful even if they fail in the courses related to English language teaching.

Table 7. Distribution of ECTS credits according to the terms in the new programme

\begin{tabular}{lclc}
\hline $1^{\text {st }}$ Term & Credits & $2^{\text {nd }}$ Term & Credits \\
\hline ELT & 8 & ELT & 13 \\
General K. & 16 & General K. & 11 \\
Pedagogical K. & 6 & Pedagogical K. & 6 \\
Total & 30 & Total & 30 \\
\hline $3^{\text {rd }}$ Term & & $4^{\text {th }}$ Term & 17 \\
\hline ELT & 17 & ELT & 3 \\
General K. & 3 & General K. & 10 \\
Pedagogical K. & 10 & Pedagogical K. & 30 \\
Total & 30 & Total & \\
\hline $5^{\text {th }}$ Term & & $6^{\text {th }}$ Term & 17 \\
\hline ELT & 17 & ELT & 3 \\
General K. & 3 & General K. & 10 \\
Pedagogical K. & 10 & Pedagogical K. & 30 \\
Total & 30 & Total & 8 \\
\hline $7^{\text {th }}$ Term & & $8^{\text {th }}$ Term & 0 \\
\hline ELT & 10 & ELT & 22 \\
General K. & 3 & General K. & 30 \\
Pedagogical K. & 17 & Pedagogical K. \\
Total & 30 & Total & \\
\hline
\end{tabular}

If ECTS credits for the courses in the first term is examined according to the system given (https://uluslararasi.yok.gov.tr/Documents/yay\%C4\%B1nlar/yuksekogretimde_yeniden_yapilanma_66 _soruda_bologna_2010.pdf ), it seems that Turkish Language 1 and Information Technology courses with their high ECTS credits are the courses which students have more workload and spend more time on during and out of class. On the other hand, foreign language courses, Reading Skills 1, Writing Skills 1, Listening and Pronunciation 1 and Oral Communication 1, have two ECTS credits each, and therefore students will think that they do not have to spend much time on them. However, these courses are related to foreign language itself and students should pay more attention to them out of class as well in order to develop those skills. 


\subsection{Results for 5 th research question}

When the new programme is compared to the former one in terms of the contents of the courses related to foreign language teaching, general knowledge and pedagogical knowledge, it seems that there are quite a lot of optional courses in the new programme. While the number of optional courses in the former programme was limited, it is considerably increased in the new one. Furthermore, there are optional courses in three fields. Students are expected to choose from among 13 foreign language teaching courses, 22 pedagogical knowledge courses and 18 general knowledge courses. It can be something positive for students to have such a large range of preferences. Nevertheless, it seems to create serious problems for academic staff in terms of their workload to have some many optional courses at the same time. In addition to that, as a result of the decrease in the number and class hours of compulsory courses for foreign language teaching and the replacement of optional ones, students can choose different courses. Consequently, it will not be possible to talk about a common criterion for English teacher candidates in terms of English language teaching.

Table 8. Distribution of compulsory and optional courses in the new programme

\begin{tabular}{lcc}
\hline & Compulsory Courses & Optional Courses \\
\hline ELT & 26 & 6 \\
General Knowledge & 8 & 4 \\
Pedagogical Knowledge & 16 & 6 \\
Total & 50 & 16 \\
\hline
\end{tabular}

When the courses in foreign language field are examined in terms of the content, they are mainly divided into two groups: English language and English language teaching. In all branches of education, field knowledge is utmost important. Teacher candidates should know the field before teaching it. This is more important in our case as English is also the medium of instruction while teaching. Therefore, an English teacher candidate should speak and write accurately and comprehend what is written and told in English. It is necessary to give pedagogical courses to English teacher candidates who are competent in 4 language skills. English language courses are the courses in which students get the chance to improve their language skills. From this perspective, it can be said that the courses in the first and second term of the former programme such as Contextual Grammar I,II, Advanced Reading and Writing I,II, Listening and Pronunciation I,II, Oral Communication I,II, Lexicology; courses in the third term Oral Expression and Public Speaking Skills, and English- Turkish Translation; and the course in the sixth term Turkish- English Translation can be called as courses for field knowledge (in our case English language). The courses in the first and second terms of the new programme such as Reading Skills 1,2, Writing Skills 1,2, Listening Skills 1,2, Oral Communication Skills 1,2, Structure of English; the course in the third term Critical Reading and Writing and the course in the seventh term Translation can be regarded in this group. The numerical comparison of the courses for English language in the former and new programmes is presented in Table 9:

Table 9. Numerical Distribution of the courses for English Language and English Language Teaching

\begin{tabular}{lcc}
\hline & Former Programme & New Programme \\
\hline English Language & 12 & 11 \\
ELT & 19 & 21 \\
Second Foreign Language & 3 & 0 \\
Total & 34 & 32 \\
\hline
\end{tabular}


The number of the total courses for English language and English language teaching look similar in both programmes. The main difference between the former and new program is in class hours and ECTS credits. Class hours for English language courses in the former programme were 34 but they are 23 in the new programme. ECTS credits given for English language courses are also low. Students wishing to have an education in English take Higher Education Entrance Exam which includes only multiplechoice questions testing reading, grammar and vocabulary knowledge. The students passing this exam can sit in a programme in which there is no preparatory class or they can be a student of a university whose proficiency exam for preparatory classes is like YDS (Foreign Language Exam) one- sided, in other words, not including all language skills. In both cases, students have to be successful in the courses in ELT department without improving their speaking, listening and writing skills. It is clear that English language courses are important for such students. As the English language courses are not enough for this purpose, the new programme looks very poor. Table 10 can give a detailed idea about the situation:

Table 10. English Language Courses

\begin{tabular}{|c|c|c|c|c|}
\hline \multicolumn{2}{|l|}{ Former Programme } & \multicolumn{3}{|c|}{ New Programme } \\
\hline Name of the course & Hours & Name of the course & Hours & ECTS \\
\hline Contextual Grammar I & 3 & - & - & - \\
\hline \multirow[t]{2}{*}{ Advanced Reading and Writing I } & 3 & Reading Skills 1 & 2 & 2 \\
\hline & & Writing Skills 1 & 2 & 2 \\
\hline Listening and Pronunciation I & 3 & Listening and Pronunciation 1 & 2 & 2 \\
\hline Oral Communication Skills I & 3 & Oral Communication Skills 1 & 2 & 2 \\
\hline Contextual Grammar 2 & 3 & Structure of English & 2 & 2 \\
\hline \multirow[t]{2}{*}{ Advanced Reading and Writing 2} & 3 & Reading Skills 2 & 2 & 2 \\
\hline & & Writing Skills 2 & 2 & 2 \\
\hline Listening and Pronunciation 2 & 3 & Listening and Pronunciation 2 & 2 & 2 \\
\hline Oral Communication Skills 2 & 3 & Oral Communication Skills 2 & 2 & 2 \\
\hline Lexicology & 3 & - & - & - \\
\hline- & - & Critical Reading and Writing & 2 & 3 \\
\hline $\begin{array}{l}\text { Oral Expression and Public Speaking } \\
\text { Skills }\end{array}$ & 3 & - & - & - \\
\hline English- Turkish Translation & 3 & Translation & 3 & 3 \\
\hline Turkish- English Translation & 3 & & & \\
\hline Total & 36 & Total & 23 & 24 \\
\hline
\end{tabular}

When the courses for English Language are examined, it is seen that Contextual Grammar courses are removed and is replaced by Structure of English course. This course with 2 ECTS credits is thought to be enough for the students to remind the rules of English language they have already known. However, in the Contextual Grammar courses, it was observed that students knew the grammar rules of English, but they were not so good at practising them. It is difficult to teach how to use the grammatical structures accurately in a two- hour-course. The separation of Advanced Reading and Writing course as Reading Skills and Writing Skills is useful for both teaching staff and students. The removal of Lexicology and Oral Expression and Public Speaking Skills courses is a great deficiency for the programme. The initial one was the course that made contributions to students' language competence and in the latter one, students used to improve their presentation skills. A three- hour- English- Turkish Translation and a three- hour- Turkish - English Translation courses are replaced by a three- hour Translation course. In this case, English teacher candidates will have less work in translation and will be less qualified in this issue.

English Language Teaching courses start in the third term. As Approaches of English Learning and Teaching course, in which students are taught methods and techniques to teach a language, is planned 
as a two- hour course, it will be limited to giving only the theoretical aspects, students will not have the chance to practise what they learn. Although New Approaches in English Language Teaching course, an optional course in English language teaching in the new programme, looks similar to Approaches for English Learning and Teaching in content and is the continuation of this course, as an optional course it will not be chosen by all the students. Therefore, the students who choose other optional courses will not be able to learn all the methods in foreign language teaching.

As the contents of the courses whose class hours were decreased such as Linguistics, Language Acquisition, Literature, Teaching Foreign Language to Young Learners, Teaching Language Skills and Language and Literature are quite rich, the topics will have to be given very fast in the new programme. Especially the courses such as Teaching Foreign Language to Young Learners, Teaching Language Skills and Language and Literature are more effective on condition that teacher candidates practise teaching in class. In the new programme, in Language and Literature course it is expected to examine literary texts in different dimensions in class. Instead of that it would be better to teach and exemplify how to use literary texts in class to teach English.

School Experience course, which was applied as 4 -hour practice and 1- hour theory, is replaced by a six- hour- practice and a two-hour- theory course called Teaching Practice 1. Observations made in School Experience course are quite important for teacher candidates. Although Teaching Practice 1 course looks similar to School Experience in content, observation will be limited as it also includes practice. Furthermore, there was a common activity plan for School Experience all over Turkey, there has not been such a plan for Teaching Practice 1 yet. Thus, it can be applied differently in faculties. Besides, teacher candidates who will not have been supported with practice at university will have to teach for the first time in real classroom environment.

Materials Development in English Language Teaching course, which is defined as an optional course in the new programme, is replaced by the course called Syllabus Design in English Language Teaching. Although this course is for designing syllabus, it includes materials development as well. In this course, students can be taught both how to design the course content and what materials to develop to teach this content. However, at state schools course contents and coursebooks are not created by teachers. They can likely make adaptations for the content.

The contents of Teaching Practice 2 and Test Preparation and Evaluation in ELT courses look similar in both programmes. Although the course called Evaluation of Classroom Learning looks as if it contained alternative assessment, it overlaps with the compulsory Test Preparation and Evaluation course in ELT course in the content which includes traditional methods. It would be better if this course focuses more on alternative assessment. If it includes alternative assessment, it should be given as a compulsory course so that all students can benefit from it.

It is suggested that all teacher candidates should take compulsorily some of the courses called optional such as English Course Book Analysis, Drama in ELT, Materials Development in ELT and New Approaches in ELT. All these courses make students more qualified as prospective English teachers. To present these courses as optional causes injustice in terms of teacher quality as students choose different optional courses.

\section{Discussion}

The education of teachers who are one of the most important stakeholders of foreign language teaching is very crucial. As far as teacher training is concerned, knowledge and skills to be gained by teacher candidates can be grouped under the titles such as field knowledge, field education, pedagogical knowledge and general knowledge. The difference of a foreign Language teacher from other teachers is in that he/ she has to use the language he/she is teaching as the medium of instruction. In other words, 
an English teacher should use English while teaching. Therefore, an English teacher should be competent enough to do so. Students at ELT department take an exam which is composed of mainly reading, grammar and vocabulary knowledge and prepared by OSYM (Student Evaluation, Selection and Placement Centre). Medium of instruction for field education courses in ELT department is English and students' English levels are expected to be at least at B2 level according to the CEFR (Common European Framework of Reference for Languages) in order to participate in the courses in ELT departments. B2 is the upper position of independent user level in the CEFR (Council of Europe, 2001). Students can start the courses in ELT departments in most universities if they pass the proficiency exam for preparatory classes. If not, they have to study English until they reach the expected level. It is necessary for proficiency exam and preparatory class programme to include 4 language skills to show students' real language performance. Asma (2018) proved in his study that ELT students with high scores in the Higher Education Entrance Exam do not show the same performance when they take an exam testing 4 language skills separately. While students have similar success at reading part, their performance in writing, listening and speaking is weaker than the expected level. Alptekin (1994) emphasizes this problem and the lecturers in Coşkun and Daloğlu's (2010) study also mention it.

It is extremely important to improve teacher training programmes in order to increase teacher quality. The programme carried out until 2018 has some deficiencies because it is clear that we still have not caught up with the expected contemporary level in terms of teacher quality. In the 2018 programme, which was prepared as a result of intensive work, courses for field knowledge (English language) and field education (ELT) are left behind the other two fields in terms of class hours, ratio of the courses and ECTS credits. Foreign language teaching is a field which has its own teaching approaches, methods and techniques. Foreign language teaching methods are based on not only learning approaches but linguistic approaches as well. The contribution of pedagogical courses on teaching is undeniable but ELT lecturers can exemplify teaching methods that belong to ELT rather than pedagogical field lecturers. The fall in the class hours, the ratio of ELT courses and the ECTS credits of foreign language teaching courses causes ELT field to look less important. This finding is similar to Yaman's (2018) study.

In the former programme in the courses such as Approaches for English Teaching, Teaching English to Young Learners, Teaching Language Skills, and Literature and Language Teaching, students were taught theoretical issues with sample lessons and then they were required to plan a lesson and teach it in class. The class hours were enough for each student to have the chance to teach at least one lesson in each course. Because of the excessive number of students in class, each student had the turn only once. However, students can see a lot of classroom applications by observing their classmates and listening to the feedback their classmate got from the teacher. In the new programme, no hours are left for practice of that kind but HEC indicates that lecturers can want students to practise if necessary (YÖK, 2018). Nevertheless, it seems that it is not possible to practise in class because of the few class hours and crowded classes. In teacher training institutions, students should be expected to practise teaching in class rather than learning only theoretical knowledge. In other words, all teaching training process should be based on teaching practice. For example, keeping the theoretical knowledge in mind, a teacher candidate should know how to plan and give a lesson to children with songs, games and suitable materials.

Studies related to ELT programmes indicate that ELT programmes should include more practice (Kaş, 1989; Seferoğlu, 2006; Coşkun \& Daloğlu, 2010; Karakaş, 2012; Uzun, 2016; MEB, 2017; YÖK, 2018). However, it seems that practice means only practice at school for HEC. In this case, the new programme contradicts its objectives (YÖK, 2018). 


\section{Conclusion}

When the new programme is evaluated from all these perspectives, it is suggested that problems of English language teacher training process should be reviewed; and ELT curriculum should be reorganised in a way that should combine theory and practice equally and can train qualified teachers equipped with English language knowledge, general knowledge, pedagogical knowledge and English language teaching.

\section{Ethics Committee Approval}

The author(s) confirm(s) that the study does not need ethics committee approval according to the research integrity rules in their country (Date of Confirmation: August 18, 2020).

\section{References}

Alptekin, C. (1994). Türkiye'de yabanc1 dil öğretmenliği. Boğaziçi Üniversitesi Dergisi. 15, 161-164.

Asma, B. (2018). Examining the relationship between English admission test (YDS- 5) and four language skills of undergraduate students (Unpublished Master's Thesis). Akdeniz University, Antalya, Turkey.

Coşkun, A, Daloğlu, A. (2010). Evaluating an English language teacher education program through Peacock's model. Australian Journal of Teacher Education. 35(6), 24-42. Retrieved from http://dx.doi.org/10.14221/ajte.2010v35n6.2

Council of Europe (2001). Common European framework of reference for languages. Cambridge: Cambridge University Press.

Harmer, J. (2007). How to teach English. Essex: Pearson Education Limited.

Karakaş, A. (2012). Evaluation of the English language teacher education program in Turkey. ELT Weekly. 4(15), 1-16.

Kaş, A. (1989). Yabancı dil öğretiminde programlar. Hacettepe Üniversitesi Eğitim Fakültesi Dergisi. 4, 323-330.

Kumaravadivelu, B. (1999) Theorising practice, practising theory: the role of critical classroom observation. In H. Trappes- Lomax \& I. McGrath (Eds), Theory in language teacher education. (pp. 33-45). Birmingham: Pearson Education Limited.

Orhan, E.E. (2017). What do teacher candidates in Turkey think about their teacher education? A qualitative study. Education and Science. 42(189), 197-216.

MEB (2017). Öğretmen strateji belgesi 2017-2023. Öğretmen Yetiştirme ve Geliştirme Genel Müdürlüğ̈: $\quad$ Ankara $\quad$ Retrieved from http://oygm.meb.gov.tr/meb_iys_dosyalar/2017_07/26174415_Strateji_Belgesi_RG-Ylan _26.07.2017.pdf

Pettis, J. (2002). Developing our professional competence: some reflections. In J.C. Richards \& W.A. Renaldya (Eds), Methodology in language teaching (pp. 393- 396). Cambridge: Cambridge University Press. 
Randall, M., Thornton, B. (2001). Advising and supporting teachers. Cambridge: Cambridge University Press.

Richards, J.C. (2000). Beyond training. Cambridge: Cambridge University Press.

Richards, J.C., Farrell, T.S. (2005). Professional development for language teachers. New York: Cambridge University Press.

Seferoğlu, G. (2006). Teacher candidates' reflections on some components of a pre-service English teacher education programme in Turkey. Journal of Education for Teaching. 32(4), 369-378.

Uzun, L. (2016). Evaluation of the latest English language teacher training programme in Turkey: Teacher trainees' perspective. Cogent Education. 3(1), 1147115. Retrieved from http://dx.doi.org/10.1080/2331186X.2016.1147115

Yaman, İ. (2018). 2006 ve 2018 İngilizce öğretmenliği lisans programları üzerine karşılaştırmalı bir değerlendirme. EKEV Akademi Dergisi. 22(76), 149-164.

Yavuz, A., Topkaya, E. Z. (2013). Teacher educators' evaluation of the English language teaching program: A Turkish case. Novitas- ROYAL. 7(1), 64-83.

Yıldırım, A., Şimşek, H. (2013). Sosyal bilimlerde nitel araştırma yöntemleri. (9th Edition). Ankara: Seçkin.

YÖK (2007) Öğretmen yetişstirme ve eğitim fakülteleri (1982- 2007). Ankara: Meteksan.

YÖK (2018a) Ingilizce öğretmenliği lisans programi. Retrieved from http://www.yok.gov.tr/documents/10279/418005112/Ingilizce_Ogretmenligi_Lisans_Programi.pdf

YÖK (2018b). Öğretmen yetiştirme lisans programlart. Retrieved from http://www.yok.gov.tr/Documents/Kurumsal/egitim_ogretim_dairesi/Yeni-Ogretmen-YetistirmeLisans-Programları/AA_Sunus_\%20Onsoz_Uygulama_Yonergesi.pdf

YÖK. Yüksek yengretimde yapılanma. Retrieved from https://uluslararasi.yok.gov.tr/Documents/yay\%C4\%B1nlar/yuksekogretimde_yeniden_yapilanma _66_soruda_bologna_2010.pdf

\section{İngilizce Öğretmenliği yeni öğretim programıyla ilgili düşünceler}

\section{$\ddot{\mathbf{O z}}$}

Eğitim Fakültelerindeki bütün anabilim dallarının programları diğer fakültelerin programlarının aksine YÖK tarafindan belirlenmektedir. 2006 yılında yapılan düzenlemenin ardından Eğitim Fakültelerindeki bütün bölümler 2018 yılında yapılan değişikliğe kadar gönderilen programı uygulamışlardır. İngilizce Öğretmenliği bölümünde de durum aynıdır. 2018 yılında YÖK öğretim programlarında değişikliğe giderek 2018- 2019 öğretim yılından itibaren uygulanmak üzere yeni programı fakültelere göndermiştir. En dikkat çekici değişiklik, alan eğitimi, öğretmenlik meslek bilgisi ve genel kültür dersleri başlığı altında seçmeli ders havuzlarının oluşturulmasıdır. Yeni programda toplam ders saati 2006 programına göre azaltılımış, ders sayısı artııştır. Milli Eğitim Bakanlığına bağlı okullarda yapılan uygulama saatleri artırılmış, daha çok gözleme dayalı olan Okul Deneyimi dersi yerine ders saati artırllarak Öğretmenlik Uygulaması I dersi konmuştur. Derslerin Avrupa Kredilendirme Transfer Sistemi (AKTS) kredileri de YÖK (2018) tarafından belirlenmiş̧ir. Kuşkusuz programın etkililiği uygulama sonuçları alındığında ortaya çıkacaktır. Yine de, yeni program incelenerek ve daha önce uygulanan programla karşılaştırılarak bir 
değerlendirme yapılabilir. Bu çalışma, yeni ve önceki programdaki alan eğitimi, öğretmenlik meslek bilgisi ve genel kültür derslerini sayıları, saatleri, ders programındaki oranları, AKTS'leri ve içerikleri açısından karşılaşıırmaktadır. Sonuç olarak, programın özellikle alan bilgisi ve alan eğitimi açısından nitelikli İngilizce öğretmeni yetiştirme konusunda ihtiyacı karşılamaktan uzak göründüğü düşünülmektedir.

Anahtar sözcükler: yabancı dil öğretimi; müfredat programları; öğretmen eğitimi; yabancı dil öğretmeni yetiştirme

\section{AUTHOR BIODATA}

Dr. F. Özlem Saka is a full-time lecturer at Akdeniz University, Faculty of Education, ELT Department, Antalya, Turkey. She has been working at university for about 33 years. She is interested in the fields of English Language Teaching, Literature Teaching in ELT, Testing in ELT and Language Teacher Training. 